\title{
Determining the Optimal Time of Gastric Emptying in Cats Using Dry or Wet Food
}

\author{
Jorge Luiz Costa Castro', Sérgio Santalucia ${ }^{2}$, Ariele Aparecida Ferreira ${ }^{3}$, \\ Clara Biange dos Santos Moratelli ${ }^{3}$, Verônica Souza Paiva Castro ${ }^{4}$, André Lacerda de Abreu Oliveira ${ }^{5}$, \\ Rogério Luizari Guedes ${ }^{6}$, Vinicius Gonzalez Peres Albernaz ${ }^{3}$, Maicol Ache Cancian \& Alceu Gaspar Raiser ${ }^{4}$
}

\begin{abstract}
Background: Pulmonary aspiration of gastric content can result in intraoperative and postoperative complications, such as regurgitation, gastro-esophageal reflux and esophagitis. There are variations among authors about the ideal period of solid and liquid fasting. Determination of the appropriate amount of food abstinence in surgical patients is important, because of the metabolic disorders that interfere in response to anesthetic protocol or surgical intervention. Thereby, this research aimed to evaluate the appropriate period of fasting for elective anesthesia and surgical procedures in cats, by analysis of gastric emptying time based on the daily energy requirement.

Materials, Methods \& Results: Seven cats of mixed breed, health and with an average weight of $2.857 \pm 0.3780$ were evaluated by gastroscopy for the presence of food and obtaining tissue samples. To evaluate the gastric emptying time, dry and moist food were offered at two different times, $8 \mathrm{~h}$ and $4 \mathrm{~h}$ before each evaluation, with an interval of seven days between each food treatment (dry and moist). There was no significant difference in all biochemical parameters evaluated (cholesterol, glucose, and lactate) in both fasting times and food types $(P>0.05)$. All animals underwent gastric biopsy for histological evaluation and urease test, to discard morphological changes. After $4 \mathrm{~h}$ it was observed dry food in all cat's stomach, however just five cats presented food in their stomach after eight hours. In other hand all the animals, which ate moist food, did not present any gastric content after four hours and eight hours of feeding. Gastric mucosa were considered normal in all cats with moderate amount of Helicobacter sp.

Discussion: The difficulty of a consensus on the fast time in cats, and the great variability of the emptying time according to the feeding type, makes this study useful as basis for future studies on fasting with wet food, as well as providing immediate clinical application in surgical routine. Only a moderate gastritis related to helicobacter sp. was detected, but even healthy animals can carry Helicobacter $\mathrm{sp}$. Four $\mathrm{h}$ of fasting time if feed the patient with $80 \%$ humidity ration improve anesthetic security of the patient with typical biochemical values. As shown, the appropriate preoperative fasting directly implies on decrease in the number of complications related to full stomach. Thus, always should take into account the possibility to perform fast in an appropriate period to prevent vomiting and aspiration, without the risk of hypoglycemia benefiting the patient and reassuring the anesthesiologist, especially in situations requiring urgent or emergency intervention. As observed through endoscopy, even eight hours of fasting with dry feed is inappropriate due to significant gastric volume of food in almost all cats. This suggests that prolonged preoperative fasting is no guarantee of low stomach volume. Wet feed can be an option for elderly and debilitated patients requiring surgical intervention within a short period of fasting. The time varies with type and volume of food that is variable according patients and different species and digestive conditions. The research were conducted with none complications. By means, this experiment it was concluded that the fasting time of 4 $\mathrm{h}$ with $80 \%$ humidity moist food allows complete gastric emptying without any complication.
\end{abstract}

Keywords: fasting, preoperative, anesthesia, cat, endoscopy.

${ }^{1}$ Escola de Ciências Agrárias e Medicina Veterinária, Pontifícia Universidade Católica do Paraná (PUCPR), São José dos Pinhais, PR, Brazil. ${ }^{2}$ Universidade do Sul de Santa Catarina, Tubarão, SC, Brazil. ${ }^{3}$ Unidade Hospitalar para Animais de Companhia (UHAC), PUCPR, São José dos Pinhais, PR. ${ }^{4}$ Programa de Pós-graduação em Medicina Veterinária, Universidade Federal de Santa Maria (UFSM), Santa Maria, RS, Brazil. ${ }^{5}$ Centro de Ciências e Tecnologias Agropecuárias, Universidade Estadual do Norte Fluminense Darcy Ribeiro, Campos dos Goytacazes, RJ, Brazil. ${ }^{6}$ Programa de Pós-graduação em Ciências Veterinárias, Universidade Federal do Paraná (UFPR), Curitiba, PR, Brazil. 7Graduação, Medicina Veterinária, UFSM, Santa Maria, RS CORRESPONDENCE: J.L.C. Castro [castrojlc@ gmail.com - Tel.: +55 (41) 3207 3273]. Rod. BR-376, Km 14, Bairro Costeira, Unidade Hospitalar para Animais de Companhia. CEP 83010-500 São José dos Pinhais, PR, Brazil. 


\section{INTRODUCTION}

On medicine, preoperative fasting became widespread after 1946, when Mandelson related feeding and pulmonary aspiration during general anesthesia for childbirth [19]. Pulmonary aspiration of gastric content is well known as a cause of morbidity and mortality in human patients submitted to surgical intervention [5,9]. Later questions has occurred in medicine, because there is no scientific evidences to recommend long periods of food deprivation in elective patients $[14,18,33]$. Fasting is recommended according to animal species and there are variations between authors about the ideal period of solid and liquid food fasting. In dogs and cats fast time ranges from a minimum of $6 \mathrm{~h} \mathrm{[3],} 8$ to $12 \mathrm{~h} \mathrm{[8]}$, around $12 \mathrm{~h}$ $[1,12,35]$ and 12 to $16 \mathrm{~h}[21]$. On animals in fast, but without water restriction there is also risk of liquid aspiration with low gastric content [20]. However, prolonged fasting can result in severe hypoglycemia and metabolic acidosis, the most common acid-base imbalance in carnivorous [17].

The determination of the appropriate period of food abstinence in surgical patients is extremely important, because it can lead to metabolic disorders that interfere directly in the animal response to inhalation anesthesia and surgical intervention. Thus, the objective of this research was to evaluate the most appropriate period of preoperative fasting for elective surgical procedures in cats exposed to two types of food at two different times prior the procedure and evaluate by direct gastroscopy visualization.

\section{MATERIALS AND METHODS}

This research was performed with 6 female, mixed breed, young-adult cats, with mean weight of $2.857 \pm 0.3780 \mathrm{~kg}$. They were maintained for 90 days at veterinary hospital, being 30 days before the beginning of the project to correct adaptation to the cattery $(70 \mathrm{~cm} \times 100 \mathrm{~cm} \times 50 \mathrm{~cm})$ and released daily in groups.

All animals received the same diet containing $31 \%$ of crude protein, $12 \%$ of fat, $3.5 \%$ of fiber, $0.2 \%$ of sodium and $0.5 \%$ of potassium. Each animal received the amount required according to daily caloric need provided at morning around $08.00 \mathrm{a} . \mathrm{m}$ and 09.00 a.m and afternoon between 17.00 p.m and 18.00 p.m. Water ad libitum was provides. About wet food, water was added to the same dry food and homogenized in a blender to maintain $80 \%$ humidity composition.
All animals underwent physical examination, and blood withdraw for complete blood count, and biochemistry assessment of alanine transferase, aspartate transferase, lactate and glucose before anesthetic procedure. Assessment of cholesterol, glucose and lactate were performed in an Accutrend Plus ${ }^{\circledR 1}$ device. These evaluations occurred before each weekly review. In order to discard any gastropathy, all cats used in the research underwent gastric biopsy through endoscopy (Figure 1A \& B) 30 days prior experiment start. Two mucosal fragments from gastric body and pyloric antrum was removed with a $2.2 \mathrm{~mm}$ double-acting serrated mouth clamp. All 7 samples obtained were fixed in $10 \%$ buffered formalin and identified blindly. After fixing, the fragments underwent standard automated histological processing and the resulting slides stained with hematoxylin eosin method of Harris and analyzed under optic microscopy.

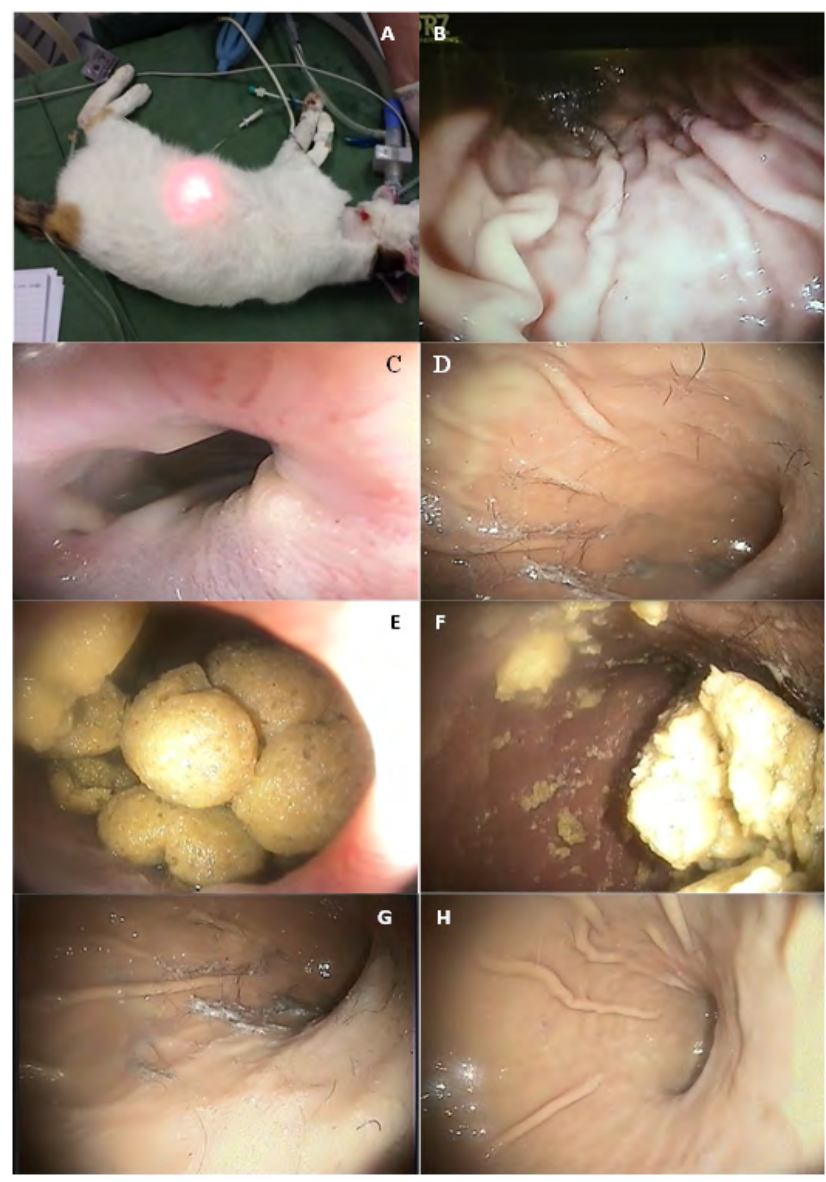

Figure 1. Feline subjected to inhalation anesthesia for exploration and biopsy of gastric cavity. (A) Patient in lateral recumbency in which makes visible the light provided by the gastroscope on the left side of the abdominal wall. (B) Visualization of stomach's body, one of the gastric biopsy sites. (C) Thoracic esophagus and sphincter cardia. (D) Pyloric antrum and pylorus evaluation. (E) Gastroscopy in a cat enables visualization of food after $4 \mathrm{~h}$ of fast with dry feed and (F) after $8 \mathrm{~h}$. (G) Gastric mucosa and pyloric antrum without food after $4 \mathrm{~h}$ of fasting with wet food and $(\mathrm{H})$ again $8 \mathrm{~h}$ after. 
After health and adaptation status confirmation, the cats were equally distributed in 4 treatments, according to type of food and time of fasting. The groups namely DF4 (dry food with $4 \mathrm{~h}$ of fast), DF8 (dry food with $8 \mathrm{~h}$ of fast), WF4 (wet food with $4 \mathrm{~h}$ of fast) and WF8 (wet food with $8 \mathrm{~h}$ of fast) and respecting a minimum interval of seven days between treatments. On the evaluation day, only $1 / 3$ of the daily caloric requirement was provides, i.e. animals with $2.5 \mathrm{~kg}$ (3 cats) received $19 \mathrm{~g}$ of food with $80 \%$ of humidity. The interval between each group evaluation was seven days.

In order to evaluate preoperative fasting, it was supplied to cats, a third of daily amount at 4 and $8 \mathrm{~h}$ of fast. The dry food used was a commercial diet for adult cats, which had $12 \%$ humidity. Wet food was prepared every time to feed the cat and consisted of adding warm water to the dry feed used previously. So, $68 \%$ of moisture was added to dry food, at the day before and at the day of assessment and examination by gastroscopy, in fast time of $4 \mathrm{~h}$ and $8 \mathrm{~h}$.

In all four assessments, the animals underwent general anesthesia, premedication with ketamine (7 mg. $\left.\mathrm{kg}^{-1}\right)$ and midazolam $\left(0.3 \mathrm{mg} . \mathrm{kg}^{-1}\right)$ associated with methadone $\left(0.3 \mathrm{mg} \cdot \mathrm{kg}^{-1}\right)$, intramuscularly. Anesthesia was induced with propofol (dose-response to allow tracheal intubation) and maintained with isoflurane and $100 \%$ oxygen. Isoflurane inspired fraction was adjusted dose-response to each patient to maintain adequate anesthesia depth for $30 \mathrm{~min}$ period.

A NTSC video-endoscope with distal tip outer diameter of $9.7 \mathrm{~mm}$ and working length of $1400 \mathrm{~mm}$ was used for endoscopy. The exam was initiated with the animal under general anesthesia in the right lateral recumbency with the passage of the endoscope by cranial esophageal sphincter under direct visualization. Initially it was observed esophageal path to the cardia, and following the lumen of the gastric body, antrum, pylorus, duodenum (Figure 1B, C \& D). After the endoscope was withdrawn to the stomach and made retroversion maneuver to assess fundus and gastric cardia. The presence or absence of any type of food in the stomach was noted in every time of fasting and correlated according to the group.

After endoscopy, all animals received tramadol hydrochloride $(1 \mathrm{mg} / \mathrm{kg}) \mathrm{IM}$, every $12 \mathrm{~h}$ and nonsteroidal anti-inflammatory meloxicam $(0.1 \mathrm{mg} / \mathrm{kg})$ IM every $24 \mathrm{~h}$. These medications were administered within $72 \mathrm{~h}$ after experiment as analgesia protocol for ovary-salpingo-hysterectomy procedure. After anesthesia recovery, food and water were free. Seventy two $\mathrm{h}$ following fast evaluation, cats underwent clinical exam and assessed returning to spontaneous feed and presence of vomiting or fecal disarrangement.

The mean serum biochemistry data in different times of fasting were compared using student's t-test with $95 \%$ probability, assuming paired data. For statistical analysis, we used one way repeated measures analysis of variance (ANOVA) and Tukey's post-test. Data are shown as mean and standard deviation. The significance level was set as $5 \%(P<0.05)$. All statistical analysis were performed using statistical software GraphPad Prism (version 3.00 for Windows, San Diego - CA, USA).

\section{DISCUSSION}

The amount of wet and dry food provided was $1 / 3$ of the daily amount of energy needed for the cats belonging to the experiment. This is due to the fact that cats habit to eat in small amounts several times a day, unlike dogs that are fed once or twice daily in accordance with owners supply.

Important to note that hematological evaluation with wet food presented values closer to normal than dry food. The normal reference interval considered in this study was are 2.1-3.3 g/dL for albumin, 73.0-134.0 $\mathrm{mg} / \mathrm{dL}$ for glucose and 40.0-86.9 mg/dL for cholesterol [16]. As noted, $4 \mathrm{~h}$ fast with crushed wet food does not have the risk of gastro-esophageal reflux and shows typical values of albumin, cholesterol, glucose and lactate.

Video-endoscopy was performed without any complications and allowed wide visualization of cardia and gastric cavity (Figure 1C 7 1D) verifying the absence of gross lesions that interfere with the trial.

The healthiness of the gastric mucosa is important as the gastric emptying time may be altered due to various factors such as: the presence of duodenal ulcers [15], pseudo-obstructions, gastritis [23] gestation [22] pain, and stress conditions of animals (restless or anxious) [2,13]. Only a moderate gastritis probably related to the presence of Helicobacter sp., in docile patients that allowed appropriate management, with successive collections of samples. Regarding the presence of Helicobacter sp., healthy animals have proven to be carriers of this organism [32]. 
In research published with dogs [2,11], canned meat and dry cereal present in the stomach of these animals were digested after $10 \mathrm{~h}$ and $52 \mathrm{~min}$ after the water intake, with observations of individual variations. In humans, the composition is also significant: it is known that the depletion of lipids is slower, faster in proteins and intermediate with carbohydrates [24]. However, in cats, the emptying time can vary among individual, according to studies [30], which observed that the total time of gastrointestinal transit is variable, although older cats have greater individual variability than younger ones. Another study assessing the gastrointestinal transit of seven young adult cats reported total transit time up to $40 \mathrm{~h}$ [7]. However, a study evaluated the oro-cecal transit time in cats measuring breath hydrogen content, and detected no differences between young cats (2-5 years) and senior cats (12-15 years) [29]. Corroborating with this, our study used young adult female cats which reduces this variability in the intestinal transit time and using food, both dry (12\%) and wet (80\%), with equal lipid, protein and carbohydrate content. Thus, in cats, the humidity factor appears to be responsible for the rapid digestion, regardless of the lipid, protein and carbohydrate content.

Literature recommends fasting time of 8 to 12 $\mathrm{h}$ and water of $4 \mathrm{~h}$ in dogs, and 6 to $8 \mathrm{~h}$ for food and hydric fasting in cats respectively [34]. As observed in this experiment, $8 \mathrm{~h}$ of fast with dry feed is inappropriate because five of seven cats had significant food volume in the stomach even after $8 \mathrm{~h}$ of fasting with dry food. Therefore, at the preoperative fasting recommendation is important to determine the type of food to be supplied as last intake until fasting. The presence of gastric contents in anesthetized patients may causa intraoperative complications, such as regurgitation and aspiration of gastric content, and postoperative, as gastro-esophageal reflux and esophagitis. In dogs there is large variation in the intensity of gastric emptying according to the type of ingested food. Dry diets were more commonly associated with increased gastric volume than canned or liquid ones, suggesting that prolonged preoperative fasting in no guarantee of low stomach volume [31]. This effect was also observed in our study with cats, in both fasting times of 4 and $8 \mathrm{~h}$, $\mathrm{s}$ when using wet feed, stomach presented without the presence of food contents (Figure 1E \& H).

Glucose level were within normal limits, was determined at time of clinical evaluation and selection of patients and $8 \mathrm{~h}$ with dry food $(91.71 \pm 22.78)$ and $4 \mathrm{~h}$ with wet food $(103.3 \pm 23.94)$ with no statistical difference between time. Hypoglycemic animals may have depression, prolonged anesthetic recovery, weakness, muscle tremors, changes in blood pressure, behavioral changes and seizures $[4,8]$. In anesthetized animals, there is no evident clinical signs of hypoglycemia, and this can only be diagnosed by blood glucose measurements [28]. Fasting induces low levels of plasma glucose, mobilizes liver's glycogen stores and reduces circulation of fatty acids, which can change biotransformation rate of drugs [34]. In this research, we do not observe changes in glucose, lactate and cholesterol levels, especially when wet food was ingested, and the stomach was already empty with 4 hof fasting.

An author reports that fasting in humans does not guarantee completely stomach empty for anesthesia induction and in health patients undergoing elective surgery, a gastric fluid volume greater than $2 \mathrm{~mL}$ can be found even after prolonged fasting time [14]. Extrapolating this data to veterinary medicine, all seven cats presented completely empty stomach at both times of 4 and $8 \mathrm{~h}$ after last intake with wet feed. We could not visualize any presence of liquid, however six stomachs showed slight amount of hair. Wet feed can be an option to nutritional management of elderly and debilitated patients requiring surgical intervention with a shorter preoperative fasting. However, $4 \mathrm{~h}$ or $8 \mathrm{~h}$ of fast did not interfere with glucose levels in animals fed with dry and wet food with $80 \%$ humidity.

The difficulty to determine a consensus of fast time in cats and the great variability of stomach emptying time according to feed type makes this study to be used as basis for future research on fasting with wet food, as well as providing immediate clinical application of $4 \mathrm{~h}$ fasting with $80 \%$ humidity diet in surgical routine, setting up anesthetic safety for patient. As shown, the appropriate preoperative fasting directly implies decrease in number of complications related to full stomach. Thus, one should always take into consideration the possibility of fast in an appropriate period to prevent vomiting and aspiration, without risk of hypoglycemia to bring benefits to patient's health and security to anesthesiologist, especially in situations requiring urgent intervention and emergencies. The time of fast varies with type of diet, volume of food, and variation between patients of different species and digestive conditions. 


\section{CONCLUSIONS}

Based on the results of this research we can conclude that pre-anesthetic fasting can be of $4 \mathrm{~h}$ when the last intake was wet food with $80 \%$ humidity and above $8 \mathrm{~h}$ to dry food, taking in account that gastric emptying may not be completed. Using wet feed with $80 \%$ humidity and $4 \mathrm{~h}$ of fast the stomach presents completely empty.

\section{MANUFACTURER}

${ }^{1}$ Roche Diagnostics. Rio de Janeiro, RJ, Brazil.
Ethical approval. All procedures, treatments and animal care were approved by Federal University of Santa Maria's Ethics Committee on Animal Research approved on 073/2011 protocol and following ethic principles of Brazilian College of Animal Research.

Funding. This research was supported by Conselho Nacional de Pesquisa - CNPq Grants n.307464/2011-3 and Universal 2012 Process n.479131/2012-0)

Declaration of interest. The authors report no conflicts of interest. The authors alone are responsible for the content and writing of the paper.

\section{REFERENCES}

1 Ambrósio A.M. 2002. Anestesia e sistema digestório. In: Fantoni D.T. \& Cortopassi S.R. (Eds). Anestesia em cães e gatos. São Paulo: Roca, pp.260-270.

2 Arnbjerg J. 1992. Gastric emptying time in the dog and cat. Journal of American Animal Hospital Association. 28(1): 77-81.

3 Bednarski R.M. 1996. Dogs and cats. In: Thurmon J.L., Tranquilli W.J. \& Benson G.J. (Eds). Lumb \& Jones Veterinary Anesthesia. 3rd edn. Baltimore: William \& Wilkins, pp.591-598.

4 Cortopassi S.R.G., Fantoni D.T., Kitahara F.R., Santos R.R. \& Conti A. 2002. Complicações da anestesia. In: Fantoni D.T. \& Cortopassi S.R.G. (Eds) Anestesia em cães e gatos. São Paulo: Roca, pp.349-361.

5 Côté C.J., Goudsouzian N.G., Liu L.M., Dendrick D.F. \& Szyfelbein S.K. Assessment of risk factors related to the acid aspiration syndrome in pediatric patients - gastric pH and residual volume. Anesthesiology. 56(1): 70-72.

6 Day M.J., Bilzer T., Mansell J., Wilcock B., Hall E.J., Jergens A., Minami T., Willard M. \& Washabau R. 2008. Histopathological standards for the diagnosis of gastrointestinal inflammation in endoscopic biopsy samples from dog and cat: a report from the Word Small Animal Veterinary Association Gastrointestinal Standardization Group. Journal of Comparative Pathology. 138(Suppl 1): S1-S43.

7 Fucci V., Pechman R.D., Hedlund C.S. \& Venugopalan C.S. 1995. Large bowel transit times using radiopaque markers in normal cats. Journal American Animal Hospital Association. 35(6): 473-477.

8 Futema F. 2002. Avaliação pré-anestésica. In: Fantoni D.T. \& Cortopassi S.R. (Eds). Anestesia em cães e gatos. São Paulo: Roca, pp.60-63.

9 Gibbs C.P. \& Modell J.H. 1994. Pulmonary aspiration of gastric contents: Pathophysiology, prevention, and management. In: Miller R.D. (Ed). Anesthesia. 4th edn. New York: Churchill Livingstone, pp.1437-1464.

10 Green C.R., Pandit S.K. \& Schork M.A. 1996. Preoperative fasting time: is the traditional policy changing? Results of a national survey. Anesthesia Analgesia. 83(1): 123-128.

11 Guimarães S.M., Oliva V.N.L.S., Maia C.A.A., Ciarlini L.D.R.P., Perri, S.H.V., Silva A.R.S. Oliveira D.B. \& Vivan M.C.R. 2007. Correlação de diferentes períodos de jejum com níveis séricos de cortisol, glicemia plasmática, estado clínico e equilíbrio ácido-base em cães submetidos a anestesia geral inalatória. Brazilian Journal Research Animal Science. 44(Suppl): 96-102.

12 Hall L.W., Clarke K.W. \& Trim C.M. 2001. Anaesthesia of the dog. In: Hall L.W., Clarke K.W. \& Trim C.M. (Eds). Veterinary Anaesthesia. 10th edn. London: Saunders, pp.385-439.

13 Hardy J.F. 1988. Large volume gastroesophageal reflux: a rationale for risk reduction in the perioperative period. Canadian Journal of Anaesthesia. 35(2): 162-173.

14 Hutchinson A., Maltby J.R. \& Reid C.R. 1988. Gastric fluid volume and pH in elective impatiens. Part I: coffee or orange juice versus overnight fast. Canadian Journal of Anaesthesia. 35(1): 12-15.

15 Jonderko K. 1987. Gastric emptying in active duodenal ulcer. Hepatogastroenterology. 34(6): 272-274.

16 Kaneko J.J., Harvey J.W. \& Bruss M.L. 1997. Appendix IX. In: Kaneko J.J., Harvey J.W. \& Bruss M.L. (Eds). Clinical biochemestry of domestic animals. 5th edn. San Diego: Academic, pp.895-899.

17 Luna S.P.L. 2002. Equilíbrio ácido-básico. In: Fantoni D.T. \& Cortopassi S.R. (Eds). Anestesia em cães e gatos. São Paulo: Roca, pp.120-129. 
18 Maltby J.R., Sutherland A.D., Sale J.P. \& Shaffer E.A. 1986. Preoperative oral fluids: is a five-hour fast justified prior to elective surgery? Anesthesia Analgesia. 65(11): 1112-1116.

19 Mandelson C.L. 1946. The aspiration of stomach contents into the lungs during obstetric anesthesia. American Journal of Obstetric Gynecology. 52: 191-205.

20 Massone F. 1999. Anestesiologia veterinária: farmacologia e técnicas. 3.ed. Rio de Janeiro: Guanabara Koogan, 225p.

21 Massone F. 2003. Considerações gerais. In: Anestesiologia veterinária: farmacologia e técnicas. 4.ed. Rio de Janeiro: Guanabara Koogan, pp.1-16.

22 Mastrocinque S. 2002. Anestesia em ginecologia e obstetrícia. In: Fantoni D.T. \& Cortopassi S.R. (Eds). Anestesia em cães e gatos. São Paulo: Roca, pp.231-238.

23 Mayer E.A. Elashoff J., Hawkins R., Berquist W. \& Taylor I.L. 1988. Gastric emptying of mixed solid-liquid meal in patients with intestinal pseudoobstruction. Digestive Diseases Sciences. 33(1): 10-18.

24 Moro E.T. 2004. Prevenção da aspiração pulmonar do conteúdo gástrico. Revista Brasileira de Anestesiologia. 54(2): 261-275.

25 Muir W.W. 2007. Considerations for general anesthesia. In: Tranquili W.J., Thurmon J.L. \& Grimm K.A. (Eds). Lumb \& Jones' Veterinary Anesthesia and Analgesia. 4th edn. Iowa: Blackwell Publishing, pp.7-30.

26 Neiger R. \& Simpson K.W. 2000. Helicobacter infection in dogs and cats: facts and fiction. Journal of Veterinary Internal Medicine. 14(2): 125-133.

27 Neiger R., Dieterich C., Burnens A., Waldvogel A., Corthésy-Theulaz I., Halter F., Lauterburg B. \& Schmassmann A. 1998. Detection and prevalence of Helicobacter infection in pets. Journal of Clinical Microbiology. 36(3): 634-637.

28 Nogueira L.C., Cortopassi, S.R.G., Intelizano, T.R. \& Souza M.S.B. 2003. Efeitos do jejum alimentar pré-cirúrgico sobre a glicemia e o período de recuperação anestésica em cães. Brazilian Journal Research Animal Science. 40(suppl 1): 20-25.

29 Papasouliotis K., Sparkes A.H., Gruffydd-Jones T.J., Cripps P.J. \& Harper E.J. 1998. Use of the breath hydrogen test to assess the effect of age on orocecal transit time and carbohydrate assimilation in cats. American Journal Veterinary Research. 59(10): 1299-1302.

30 Peachey S.E., Dawson J.M. \& Harper E.J. 2000. Gastrointestinal transit times in young and old cats. Comparative Biochemistry and Physiology Part A. 126(1): 85-90.

31 Savvas I., Rallis T. \& Raptopoulos D. 2009. The effect of pre-anaesthetic fasting time and type of food on gastric content volume and acidity in dogs. Veterinary Anaesthesia and Analgesia. 36(6): 539-546.

32 Solnick J.V. \& Schauer D.B. 2001. Emergence of diverse Helicobacter species in the pathogenesis of gastric and enterohepatic diseases. Clinical Microbiology Reviews. 14(1): 59-97.

33 Strunin L. 1993. How long should patients fast before surgery? Time for new guidelines. British Journal of Anaesthesia. 70(1): $1-3$.

34 Thurmon J.C., Tranquilli W.J., Benson G.J. \& Martin D.D. 1996. Anesthesia for Special Patients: Neonatal and Geriatric Patients. In: Thurmon J.L., Tranquilli W.J. \& Benson G.J. (Eds). Lumb \& Jones. Veterinary Anesthesia. 3rd edn. Baltimore: William \& Wilkins, pp.844-848.

35 Trim C.M. 1987. Considerations and complications. In: Short C.E. (Ed). Principles \& Practice of Veterinary Anesthesia. Baltimore: Williams \& Wilkins, pp.261-262. 